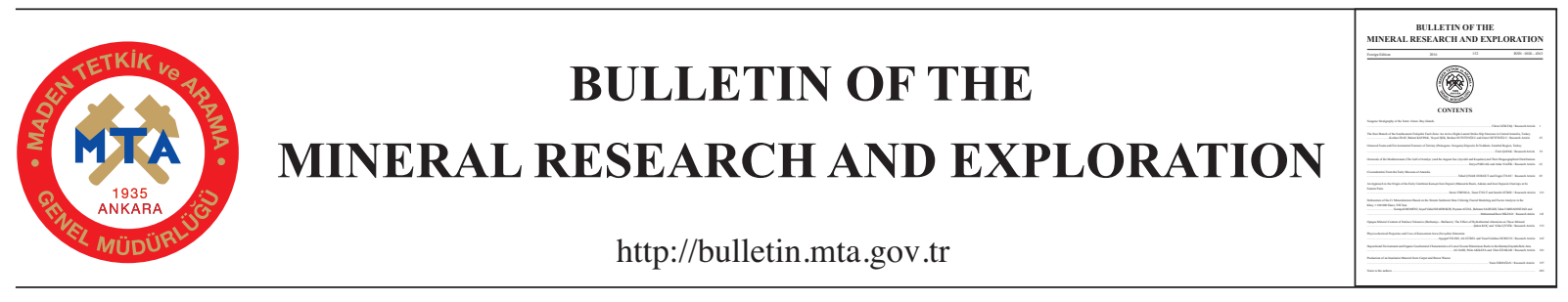

\title{
OPAQUE MINERAL CONTENT OF DUTLUCA VOLCANICS (BURHANIYE - BALIKESİR): THE EFFECT OF HYDROTHERMAL ALTERATION ON THESE MINERALS
}

\author{
Şükrü KOÇ and Nihal ÇEVIKK* \\ ${ }^{a}$ Ankara University, Faculty of Engineering, Dept. of Geological Eng., 06100, Tandoğan, Ankara
}

Research Article

Keywords:

Hydrothermal Alteration,

Pyrite, Enargite,

High Sulfidation, Ore

Microscopy

Received: 28.02 .2015

Accepted:23.03.2015

\begin{abstract}
Dutluca volcanics, which are known as Hallaçlar Formation in regional scale in the study area (Kurshensky, 1976), are composed of hydrothermally altered andesite and basaltic andesite. In these rocks, sulfidic minerals such as pyrite, enargite and chalcosine, and oxide and hydroxide minerals such as magnetite, hematite and goethite were detected as opaque minerals. The presence of enargite in opaque mineral paragenesis, and the changes observed in structures and textures of opaque and silicate minerals indicate that examined volcanics have been altered by highly sulfidic hydrothermal solutions. During the hydrothermal alteration process, which indicates at least in two phases, a diffuse pyritization rich in $\mathrm{H}_{2} \mathrm{~S}$ in reducing conditions and enargite mineral, which is known as pathfinder minerals in such processes, formed in the first phase. Later on; the extensive martitization developed in oxidizing conditions.
\end{abstract}

\section{Introduction}

Tertiary volcanics, which are located in the study area, are regionally known as Hallaçlar formation (Kurshensky, 1976). This formation is composed of andesites and is affected from low and high sulfidic hydrothermal solutions. For instance; in volcanics around Küçükdere (Havran-Balıkesir) (Çolakoğlu, 2000; Çolakoğlu and Kuru, 2001) gold deposit, quartz \pm calcite \pm adularia \pm illite paragenesis was detected indicating the low sulfidation (Hedenquist, 1985, Simmons et al., 2005). However; the high sulfidation alteration with quartz \pm alunite \pm prophyllite \pm dickite \pm kaolinite paragenesis is observed in Kirazlı and A $\breve{g}_{1}$ mineralization area (Yiğit, 2012). The purpose of this study is to obtain data on opaque mineral component of the volcanics which were affected from the alteration around Dutluca, the effects of hydrothermal solutions on opaque and ferrous silicate minerals (opacification), and the types of solutions which generated these effects. There are several methods that can be applied to reach this goal. Here, it is just intended that the results obtained from ore microscopy would contribute to other methods. Andesites mostly consist of plagioclase (oligoclase, andesine, sometimes labradorite) and few amounts of mafic minerals such as; hornblende, biotite, pyroxene. As accessory minerals; magnetite, ilmenite and apatite are observed. Hornblende and biotite minerals in these rocks turn into chlorite, sphene and iron oxide by hydratation. Plagioclase minerals turn into epidote, sericite, kaolinite and quartz. Besides; alterations such as silicification, albitization, kaolinitization and saussuritization can be seen in andesites.

Primary opaque and ferrous silicate minerals of which andesites contain could provide some new opaque minerals to occur by (mafic) alteration. For example; pyrite formations can be observed in many epithermal systems. Sulphur bearing solutions first enter into a region and precipitate, and form plenty of pyrite which react with iron in the rock. Other subsequent metals may form new sulfide minerals. (Krauskopf, 1987). 
Hematite, which is a stable mineral of iron in intermediate and strongly oxidizing environments, is frequently available in volcanic rocks. This occurs due to the oxidation during cooling events, and it is generally observed as martite lamellae. The alteration of pyrite into hematite is not rare in volcanic hydrothermal formations (Ramdohr, 1969).

Opaque minerals which the volcanics consist of, their relationships with mafic silicate minerals and the determination of associating and altering minerals may help reach some data about alterations. With this purpose, several volcanic rocks collected from the study area were polished and examined under the ore microscopy, and their opaque mineral components and alteration structures/textures were detected. Finally; the mineralogical results which could define the composition of hydrothermal solution that causes alteration and the type of the developing alteration have been discussed in this article. The type of hydrothermal alterations and types of solutions that cause alteration can guide mineral explorations in such fields.

\section{Geological Setting}

The region, which covers the study area, consists of Paleozoic, Mesozoic and Cenozoic rocks (Figure 1). The oldest rock assemblage in the region was named as the Kazdağ group and is composed of pre-Permian metadunite, metagabbro, pyroxenite, amphibolite, gneiss and marble (Bingöl et al., 1973). These rocks outcrop around Kozak pluton (Figure 1). The plutonism has become affective after Upper Cretaceous, and Eybek and Kozak plutonic massives have been emplaced. Both massives show big resemblance in terms of chemistry, mineralogy, location and age (Ercan et al., 1984). Ercan et al. (1984, 1990) determined Miocene lavas mostly as andesitic, occasionally dasitic and rarely rhyodasitic in the investigation they had carried out on widespread Tertiary rock units. However, Pliocene lavas were detected as basaltic type in their study. The same investigators also detected that Miocene lavas had totally been calcalkaline and had the character of crustal origin. Pliocene aged Dededağ basalt is observed as small outcrops in the region. These rocks have cut Tertiary units and flown over them (Akyürek and Soysal, 1978). Pliocene-Middle Miocene alluvial and lacustrine deposits widespread in the region are encountered as Neogene formations. Alluvials have been formed by the erosion and transportation of old rocks in the area (Akyürek and Soysal, 1978).

Magmatic rocks in the Biga Peninsula are crustal origin, and the effects of upper mantle derived magma are occasionally observed. Most probably, these rocks were formed by the partial melting of lower parts of the increasingly thickening continental crust starting from Lower Eocene, after the collision of Anatolides with Pontides. Partial melting processes at depths have started in this thickening continental crust, and the metamorphism has become effective in the region. Kozak and Eybek granodioritic plutons and Hallaçlar - Dedetepe - Yuntdağ volcanics can be the products of the same calcalkaline magma, and have been formed within small time difference. However, the material of the rising upper mantle have intruded into the crust and formed hybrid magma, thus Yuntdağ volcanics have become hybridized towards its final stages and acquired partially shoshonitic character. Later on; mantle effects have increased and much siliceous, hybrid Alibey and Dededağ basalts have formed. Actually; the formation of alkali basaltic volcanism (Kula example), which is the product of primary magma, starting from Upper Pliocene in West Anatolia also indicate this situation due to the increase in mantle effect and depletion in melting crustal material in time (Ercan, 1982, Ercan et al., 1983).

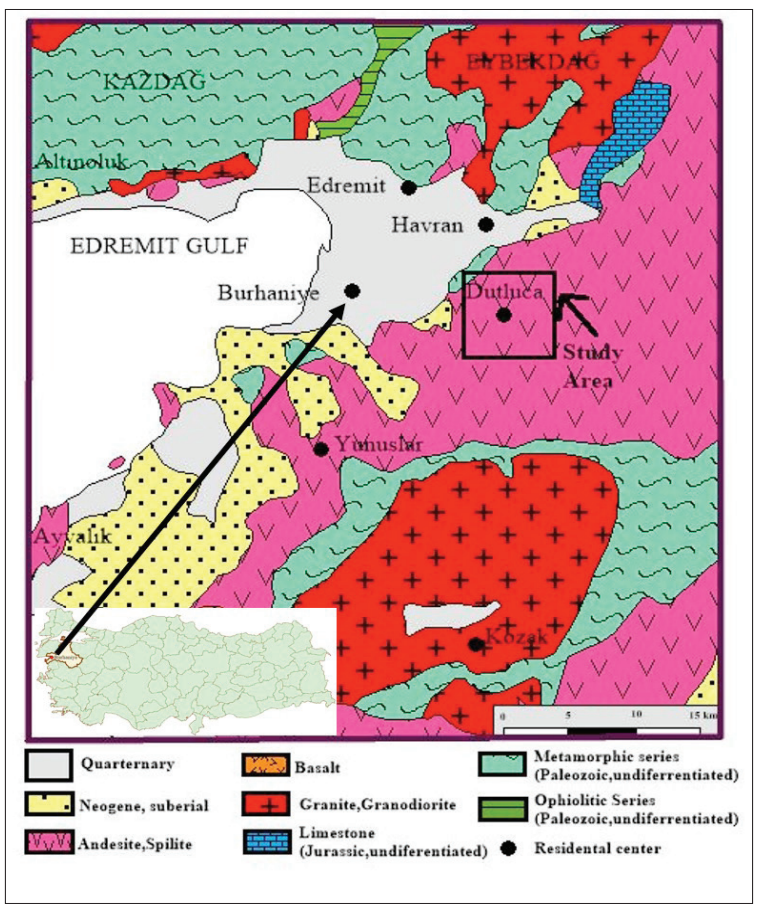

Figure 1- Geological map of the study area (from Çolakoğlu, 2002). 
Volcanics outcropping in NE of Dutluca village (Figure 1) are composed of andesite and basaltic andesites. These rocks were named as Hallaçlar formation by Kurshensky (1976) in the northern part of the study area. Rocks are generally hypocrystalline and porphyritic texture, and are composed of plagioclase, pyroxene, biotite, amphibole and opaque minerals. Plagioclase minerals in samples exhibit zoning or polysynthetic twinning. It is also possible to encounter plagioclase microliths in some samples of which their matrices are unaltered. Biotite, amphibole and pyroxene phenocrysts, which generally exhibit opacitization in circumferences, have also full opacified forms. While extensive argillization and carbonation were observed in rocks, the chloritization, sericitization and epidotization were also encountered. Using biotite minerals in andesite rocks belonging to Hallaçlar formation, dating by K/Ar method was also performed, and the age of andesites were determined as Early Neogene (23.6 $\pm 0.6 \mathrm{my}$, Middle Miocene) (Kurshensky, 1976). However; the K/ar age of andesite bearing whole rock sample was found as $26.5 \pm 11 \mathrm{my}$ in other investigation carried out by MTA. Thus, the volcanism started to become effective in Late Oligocene and has continued its effectiveness until Early Miocene (Yüzer and Tunay, 2012).

\section{Opaque Mineral Contents of Volcanics}

Several polishing were performed for field and drill samples during field studies and they have different macroscopic views to examine under ore microscope. Thus; sulfide minerals like; pyrite, enargite and chalcosine, and oxide and hydroxide minerals like; magnetite, hematite and goethite were detected in Dutluca volcanics which had been affected from the hydrothermal solution.

\section{Pyrite (FeS)}

In volcanics, two pyrite formations were detected which are different from each other. These are disseminated pyrites in the rock (Figure 2) and pyrites which are the alteration mineral of ferrous silicate minerals like amphibole and biotite (Figure 3).

1. There are two types of pyrites as disseminated within rock. These are defined as; "Pyrite 1" and "Pyrite 2" because they have different grain sizes and the matrix in which they are located.

Pyrite 1: Located in fine grained, pale gray matrix and are disseminated throughout the rock (Figure 2). In some samples they are also encountered as fully limonitized pyrite pseudomorphs (Figure 4).

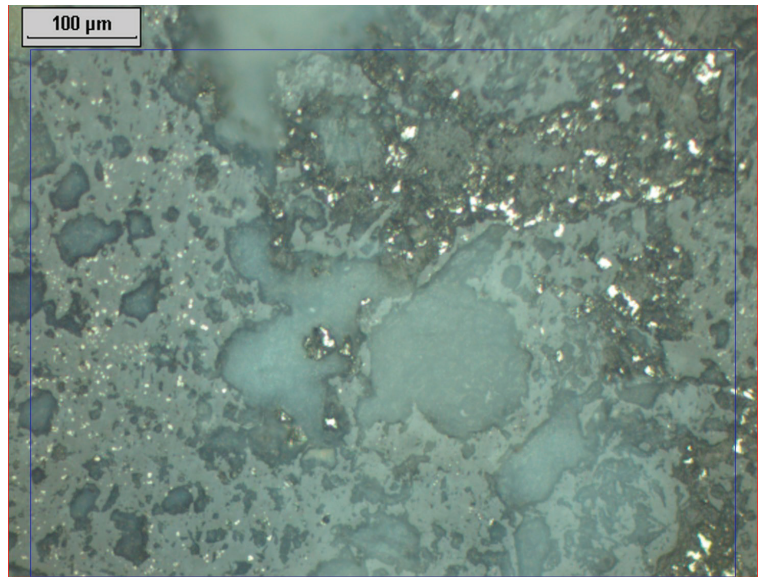

Figure 2- Disseminated pyrites in the rock. Pale gray colored pyrites on the left in matrix are finer grained. Gray and black colored pyrites are gangue minerals.
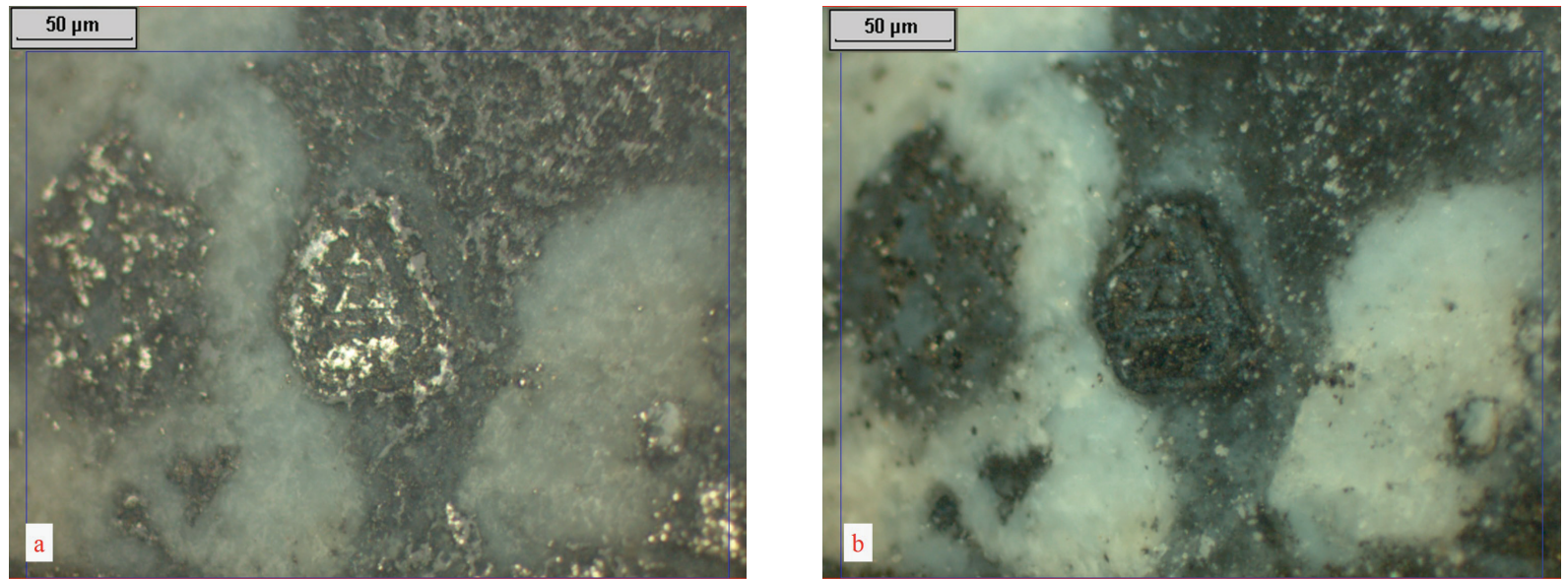

Figure 3- The pyritized amphibole on edges and crystallographical directions. Triangular shaped pyrite with zoning structure and surrounding silicates are seen at the center $(\mathrm{b}:+\mathrm{N})$. 


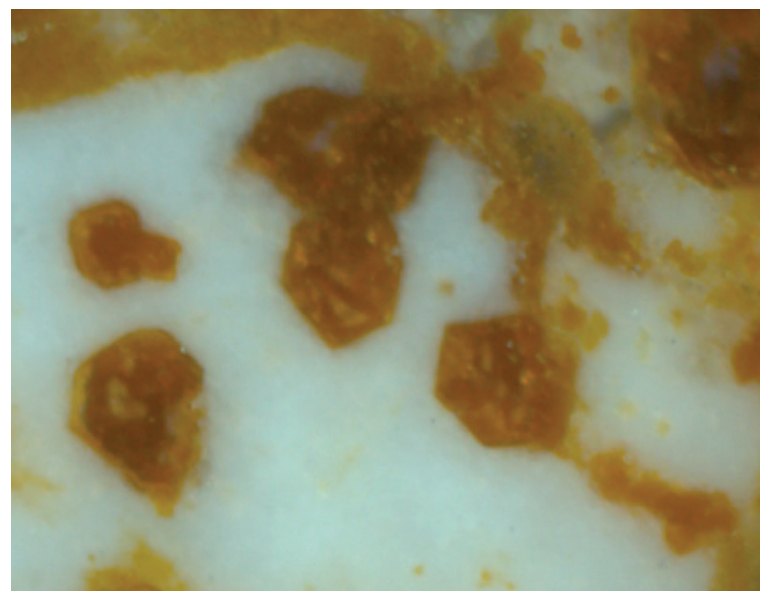

Figure 4- Euhedral and subhedral pyrites fully altered into geothite $(+\mathrm{N})$.

Pyrite 2: They are much coarser grained than Pyrite 1 as disseminated within dark gray matrix and abundant. Dark gray matrix surrounds the pale gray matrix and occasionally intakes (Figure 5). This situation and the intrusion of coarse grained pyrite bearing dark gray matrix into Pyrite 1 bearing pale gray matrix indicate that first Pyrite 1 then Pyrite 2 have formed (Figure 6).

2. Pyrite minerals (alteration product of ferrous silicate minerals)

Pyrites have formed due to the alteration of silicates like amphibole and biotite minerals. These pyrites, of which their formations depend on silicates (Figure 3), exhibit various structural and textural characteristics. Some pyrites, which were categorized in this group, are located at inner parts of the ferrous silicate minerals encircling grains partly or fully on the edges (Figure 7) and as emplaced in crystallographical directions (Figure 8). It is seen that such alterations of silicates cause zoning structures (Figure 3). However; other pyrites are located in the form of seriates with respect to the boundaries of silicate minerals (Figure 7). Besides; the secondary pyrites are also available which emplaced into cracks and fractures close to these formations (Figures 7 and 9).

\section{Enargite $\left(\mathrm{Cu}_{3} \mathrm{AsS}_{4}\right)$}

Enargite, in studied samples, are pale pinkish, brown and gray colored, and exhibit strong anisotropy. The colors of anisotropy are yellowish, brownish, orange like and greenish gray. Although enargite is confused with luzonite and stibioluzonite in its group, these two minerals have very strong twin lamellae and much orange colors.

As it was in pyrites, two different formations of enargite were detected too. Enargite 1 is seen as disseminated in altered volcanic rocks and is very fine

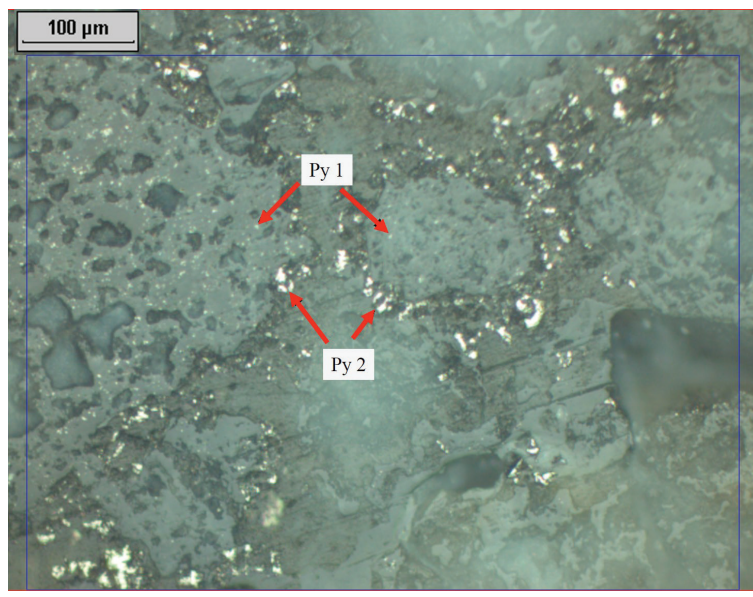

Figure 5- Two different matrices, two different pyrites. Fine grained "Pyrite 1" within pale gray matrix, and "Pyrite 2" coarser and more abundant than dark gray colored Pyrite 1 in matrix. Matrix with Pyrite 2 completely surrounds the other.

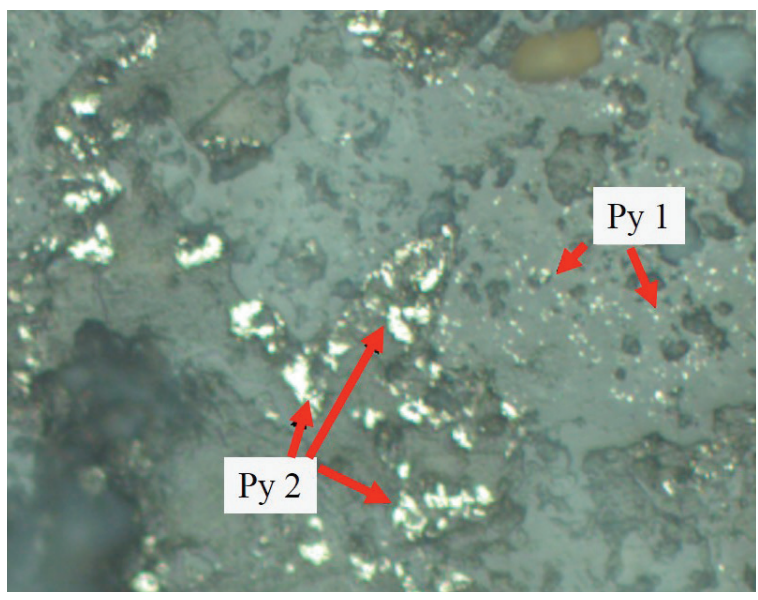

Figure 6- Central part: dark gray matrix which contains coarse grained "Pyrite 2" penetrates into "Pyrite 1" bearing dark gray matrix.

grained (Figure 10). Enargite 2, on the other hand, are the alteration products of ferrous silicate minerals like amphibole and biotite. These enargites, which formed by silicates, are encountered together with hematites (Figures 11, 12, 13, 14, 15). In figure 13, there are observed hematite and enargite formations in the outer and inner parts of amphibole mineral, respectively. There were also detected enargites which emplaced into cracks and fractures and these are associated with silicates. For example; the enargites which accumulated on the edge of cavity is seen in figure 15 . There is also seen that this enargite turns into another yellow colored sulfide mineral starting from edges. This is probably a pyrite mineral, and it is known that enargite could change into various sulfide minerals like chalcosine, pyrite, chalcopyrite, covelline and galenite (Ramdohr, 1969). 

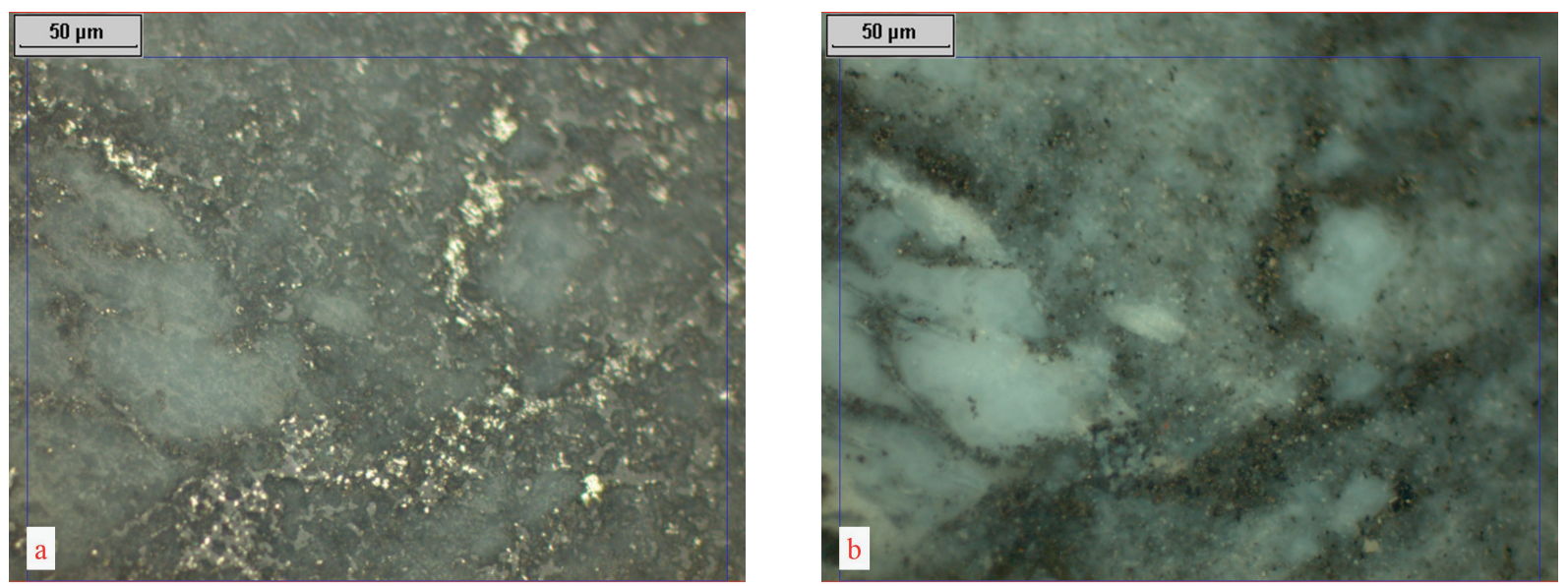

Figure 7- Pyrites placed around bluish gray gangue mineral in the form of "S" shape and into the fracture of matrix along a line.

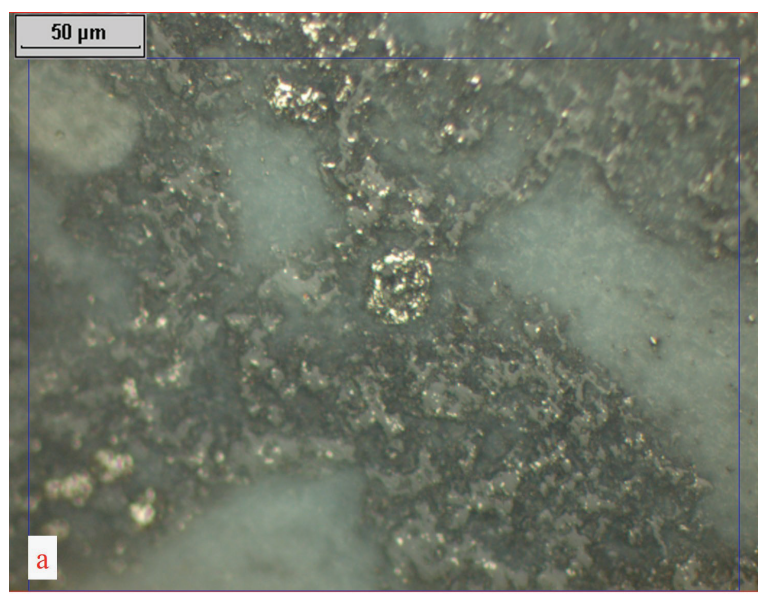

Figure 8a- Pyritized amphibole (b: $+\mathrm{N})$.

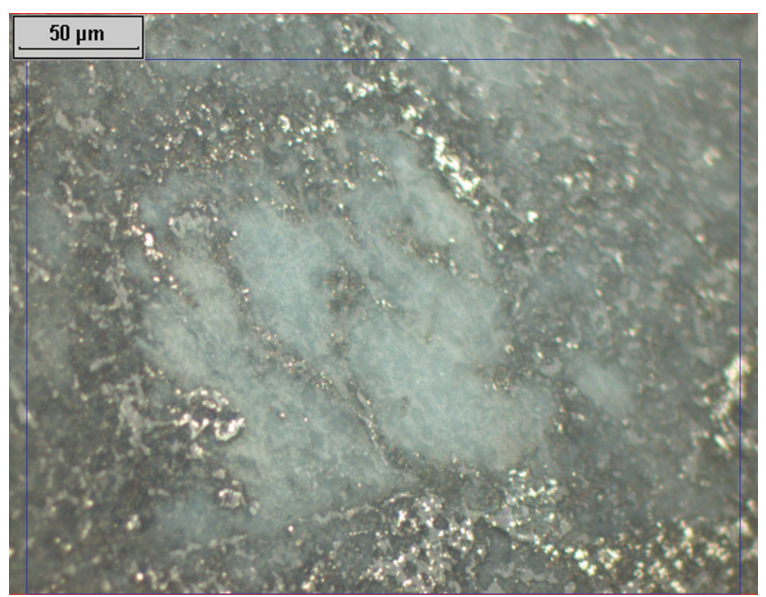

Figure 9- Pyrites placed around the edges of matrix and fractures.

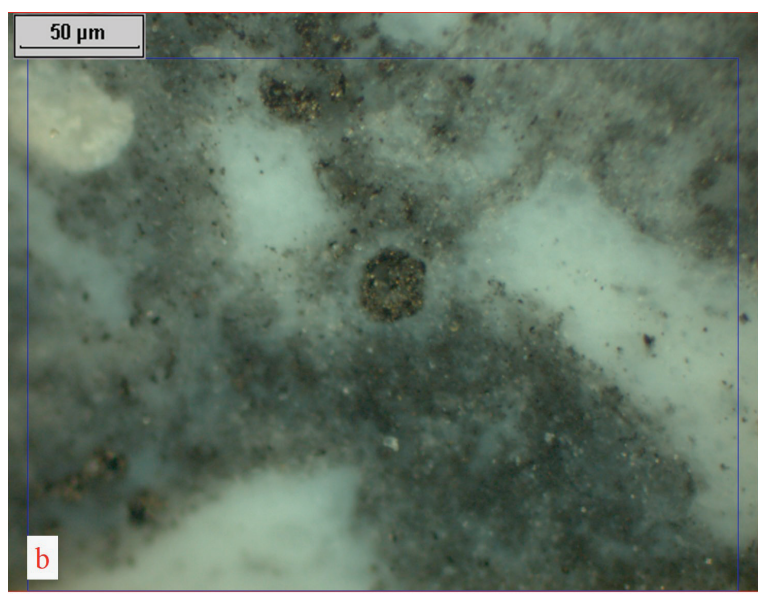

Figure $8 \mathrm{~b}$ - Pyritized amphibole $(\mathrm{b}:+\mathrm{N})$.

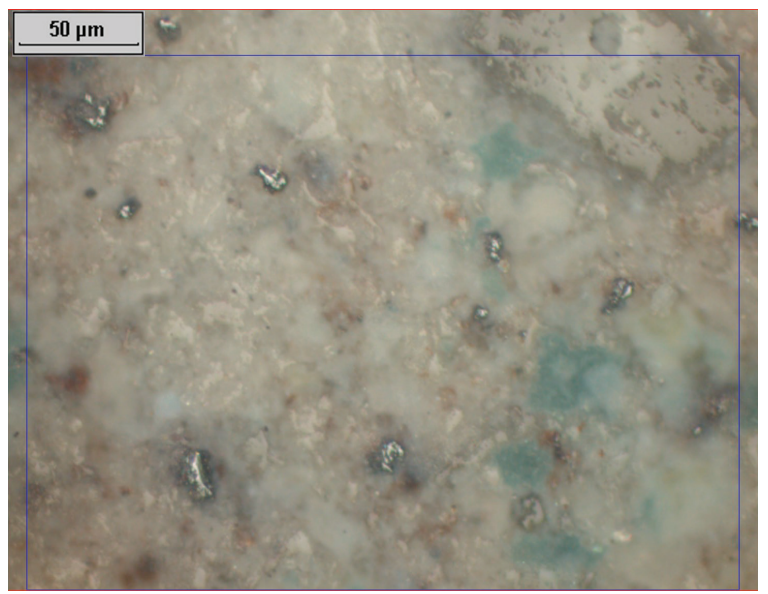

Figure 10- Very fine enargite grains dispersed in the rock. 


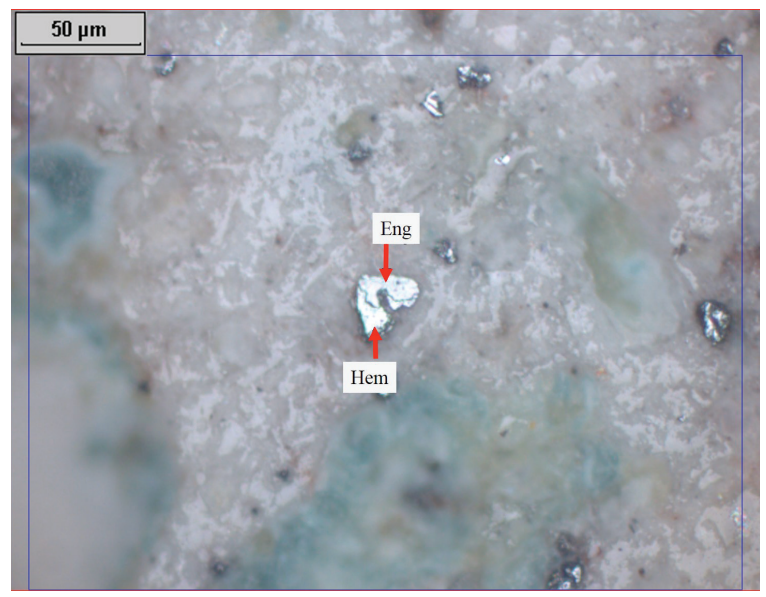

Figure 11- Hematite and enargite.

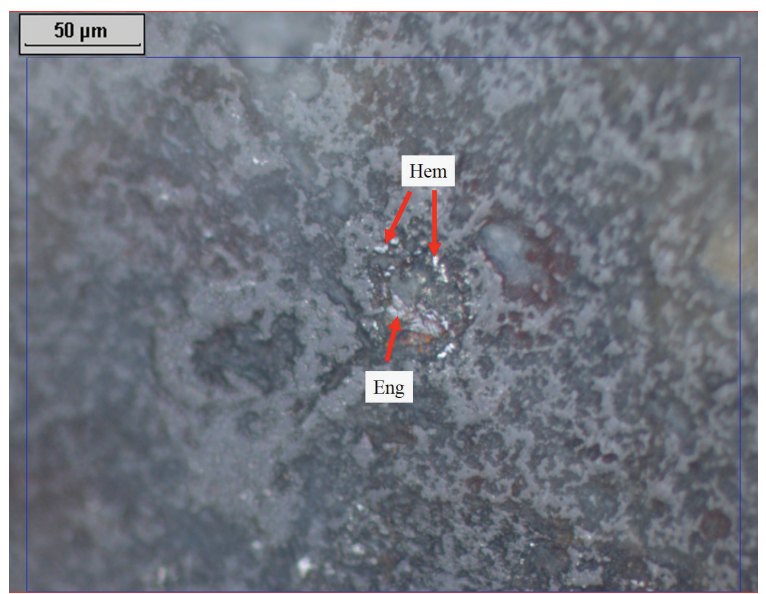

Figure 13- Formation of hematite around highly altered amphibole and enargite formation in the nterior part.

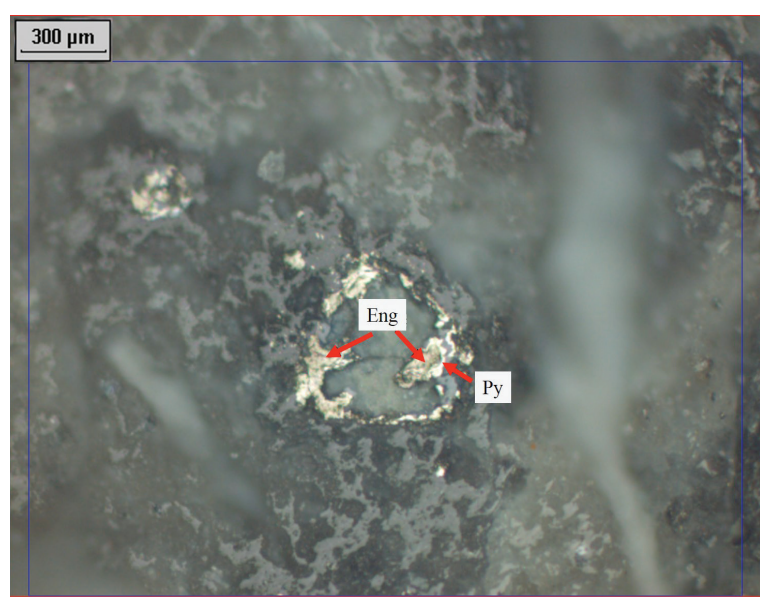

Figure 15- Enargite which precipitated around the edges of void. Enargite has turned into another sulfide mineral starting from the edges of enargite. The void has then been filled by matrix.

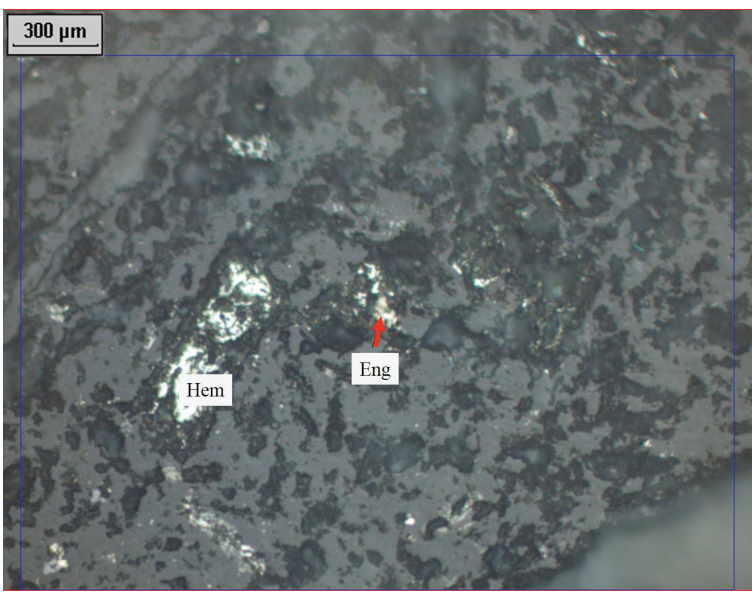

Figure 12- Hematite and enargite.

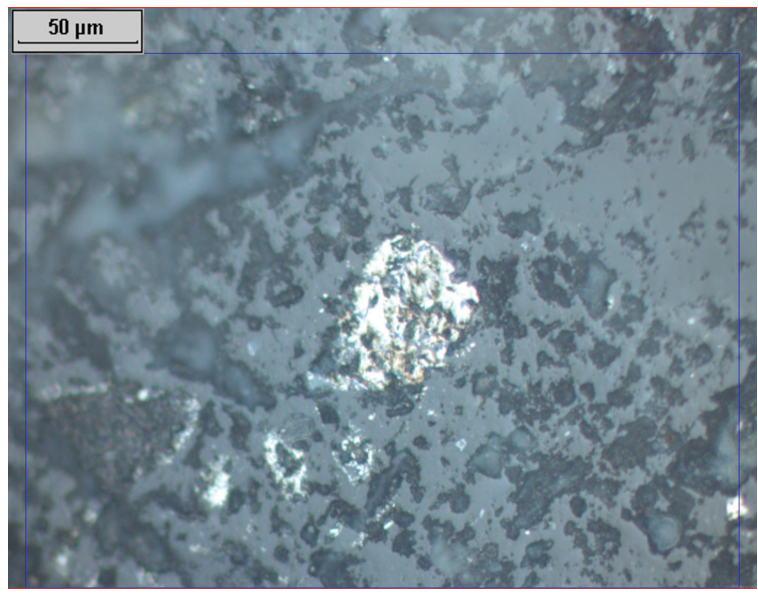

Figure 14- Enargite.

\section{Chalcosine (CuS)}

Chalcosine, which was observed only in one of all the polished samples in the study area, is seen as associated with hematites (Figure 16). This chalcosine exhibits anisotropy and is a secondary mineral. It is probably the alteration product of enargite.

\section{Magnetite $\left(\mathrm{FeOFe}_{2} \mathrm{O}_{3}\right)$}

In samples, subhedral magnetites are seen less than pyrite as disseminated in the rock (Figures 17 and 18). In these magnetites, the martitizations (hematitizations) are encountered in various degrees (Figure 19). Magnetites have mostly been hematitized starting from edges (Figures 19a and 19b). Besides, the rod like hematitizations, which developed along crystallographical directions of the magnetite, are not seldom (Figure 19a). In figure 20, the hematitization 


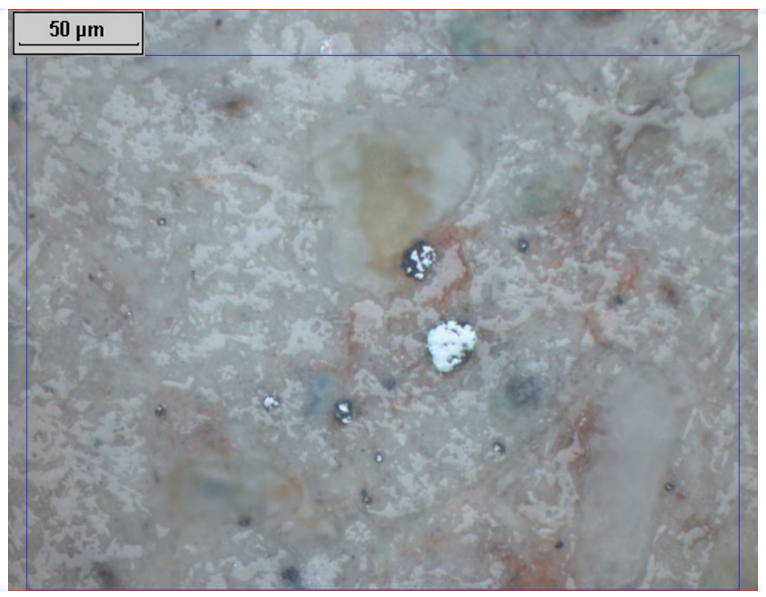

Figure 16- Chalcosine (coarse, whitish gray) and hematite (grayish white).

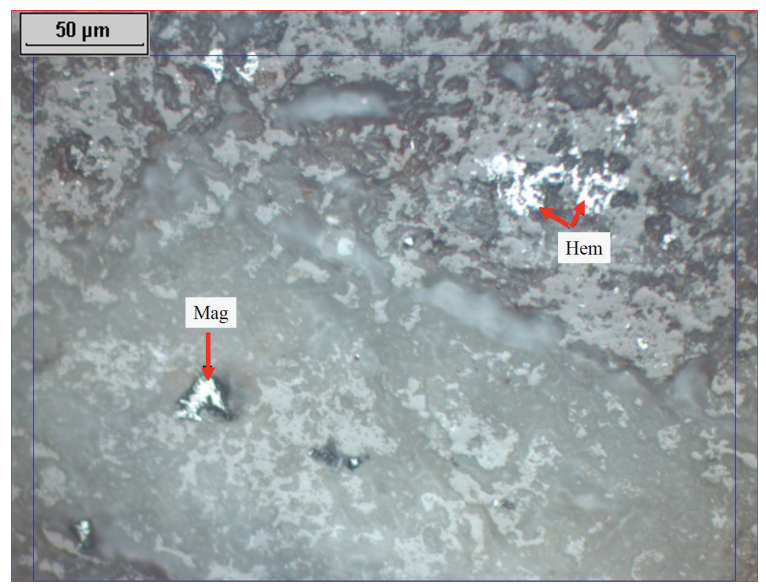

Figure 18- Euhedral (triangle) and subhedral magnetite and hematites in upper right. Both minerals were substituted by the matrix.

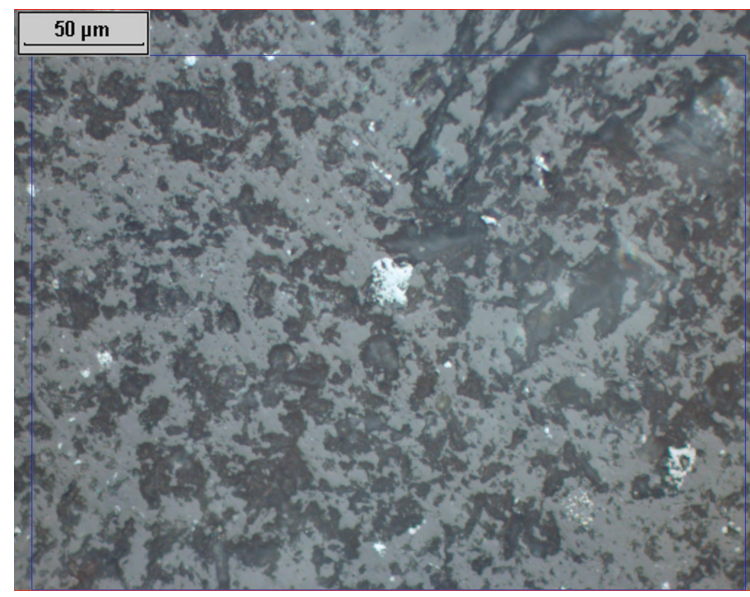

Figure 17- Subhedral magnetite in the center.

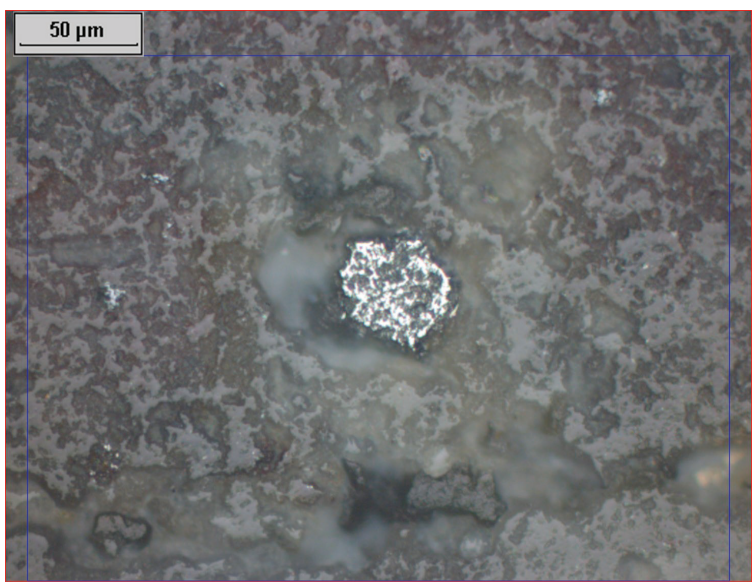

Figure 20- The hematitization of a euhedral magnetite.
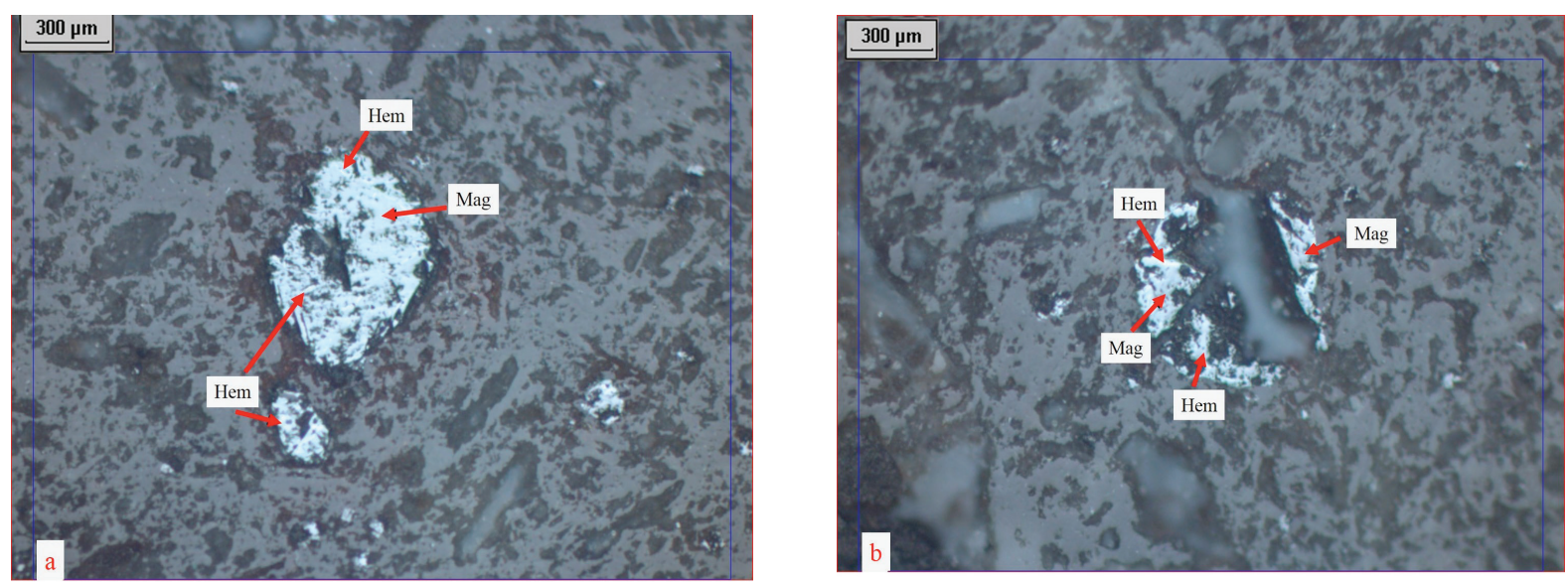

Figure 19- Hematitized (martitized) and highly substituted magnetite mineral by matrix (a, b). 
of euhedral magnetite is seen. In samples, where magnetite mineral was hematitized then limonitized, these three minerals associate with each other.

\section{Hematite $\left(\mathrm{Fe}_{2} \mathrm{O}_{3}\right)$}

The most abundant opaque mineral after pyrite is hematite, and is secondary origin. Some hematites are the alteration product of opaque minerals. Many amphibole grains in samples turned into hematite in various shapes by the effect of alteration. In figure 21, the alteration in which the cleavages of hornblends are seen is observed. It is frequently seen that the amphibole alters into hematite from edges and inner parts (Figure 22). As an alteration product of amphibole, the association of hematite and enargite is also observed (Figures 12 and 13). Besides, the pseudomorphs in which euhedral amphibole fully hematitized were also detected (Figure 23). Hematitizations were also observed starting from edges in biotites in ferrous silicates (Figure 24).

The iron, which is dissolved from mafic minerals during the alteration of volcanics, has substituted carbonates in the form of hematite (Figure 25). A significant portion of secondary hematite formations are associated with opaque minerals. Pseudomorphic euhedral and subhedral hematites, which are observed as disseminated (Figure 26), are bonded to the primary origin opaque minerals. Triangular and rectangular shaped hematites can be given as examples to this phenomenon (Figure 27). The hematitization of a euhedral magnetite is seen in figure 20 . The partly (Figure 28) or fully (Figure 29) limonitization of secondary hematites is a frequent situation.

\section{Geothite (FeOOH)}

Geothite minerals were encountered as an alteration product of opaque or ferrous silicate minerals in many polished samples. Geothites formed by opaque minerals are in the form of hematitemagnetite-goethite mineral association (Figure 22), or as hematite-geothite mineral association (Figure 29). However; geothites formed by ferrous silicates only associate with hematite (Figures 30 and 31), and the formation of temporal limonite and iron staining are seen in the form of fracture in samples (Figure 4).
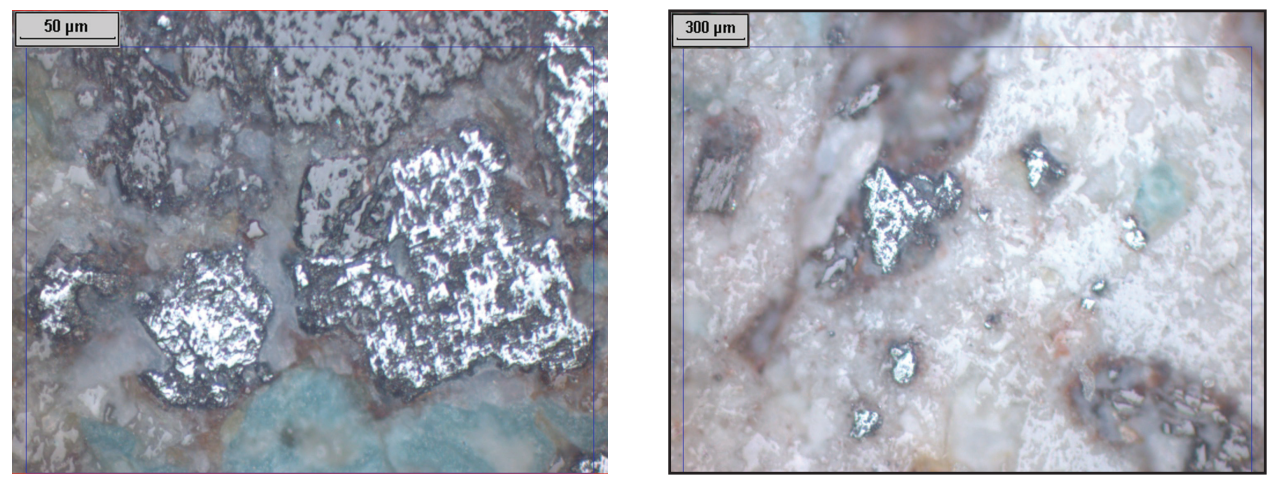

Figure 21- Hematite formed by hornblende (white). Typical cleavage traces of the hornblende can be seen.

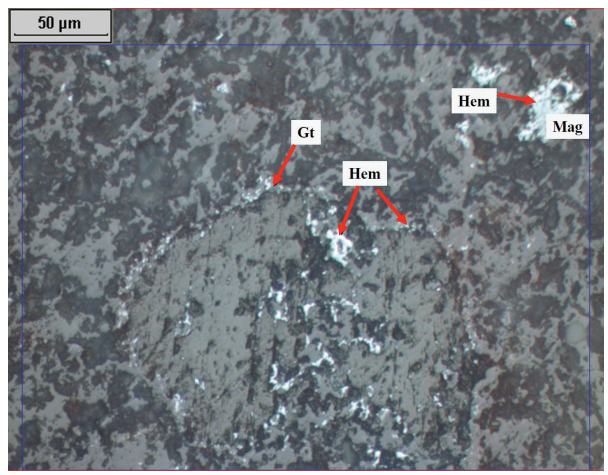

Figure 22- Hematite, magnetite and goethite: Partly hematitized goethite in the upper right, goethite around a coarse amphibole in the central part and a belt formed by very fine grained hematites and hematite in interior parts of amphibole.

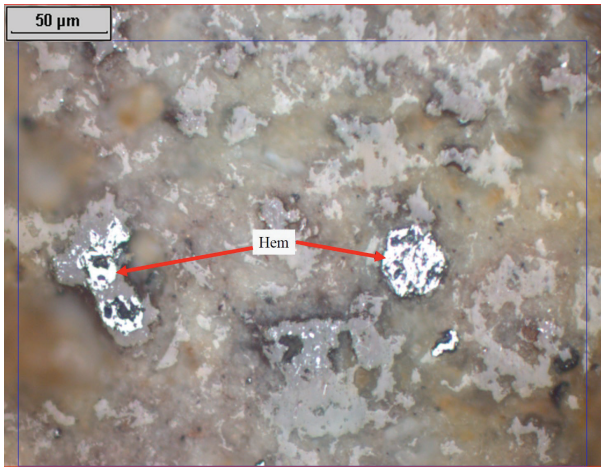

Figure 23- Fully hematitization of euhedral ferrous silicate mineral (amphibole) (pseudomorphose). 

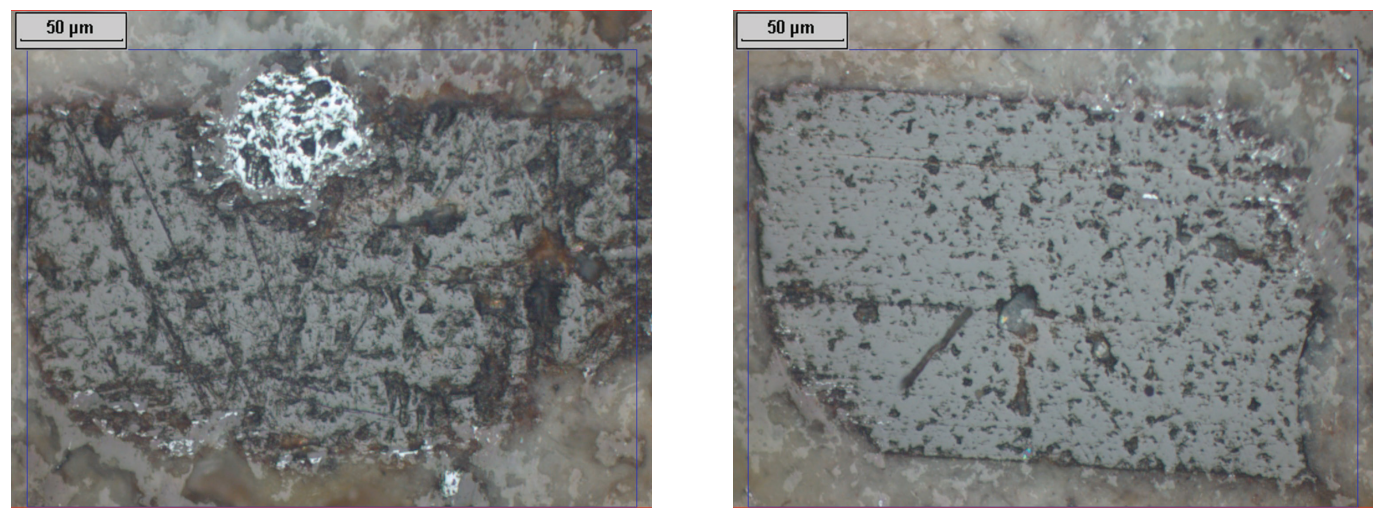

Figure 24- Hematitization starting from the circumference of euhedral biotite grain.
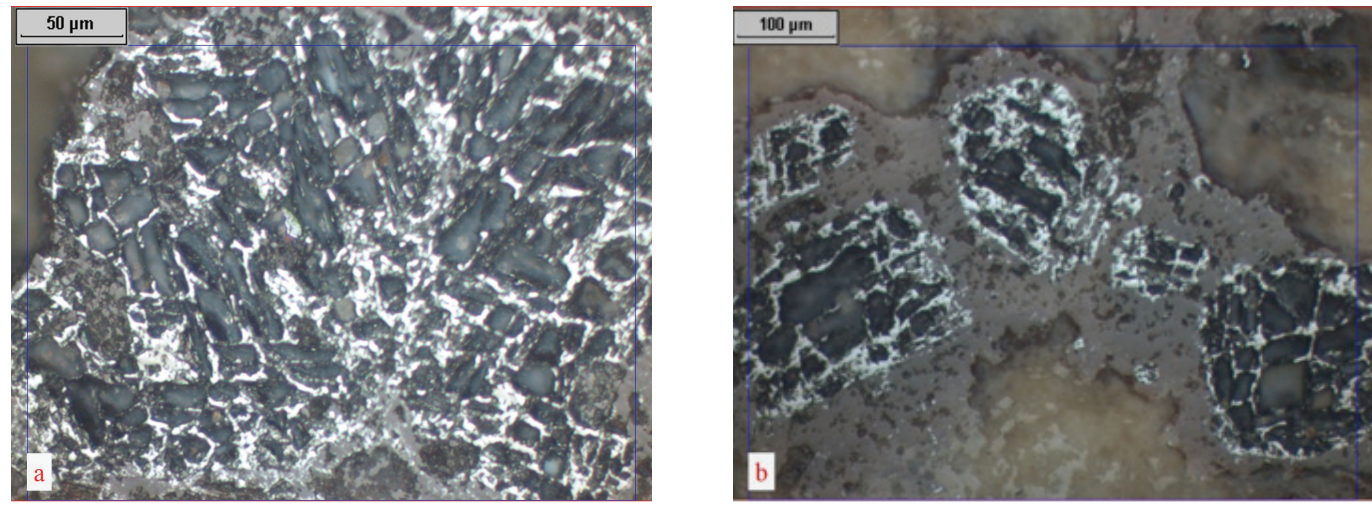

Figure 25- Hematites which substitute carbonates. Hematizations that form along $75^{\circ}$ cleavage, which is a typical characteristic of carbonates, display a cell texture $(a, b)$.

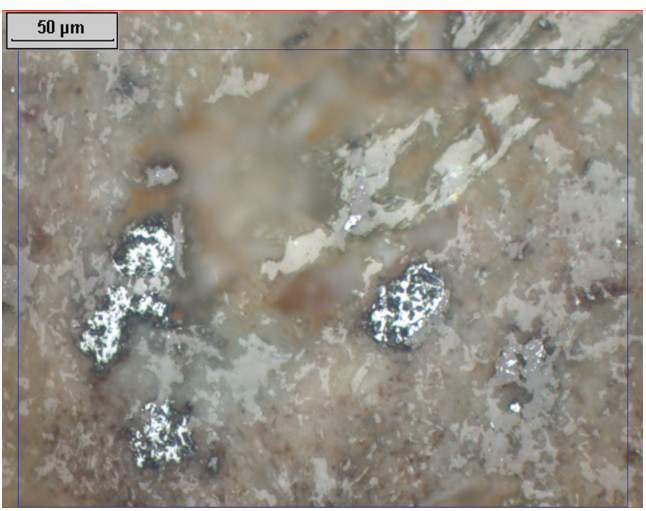

Figure 26- Anhedral hematites in the rock.

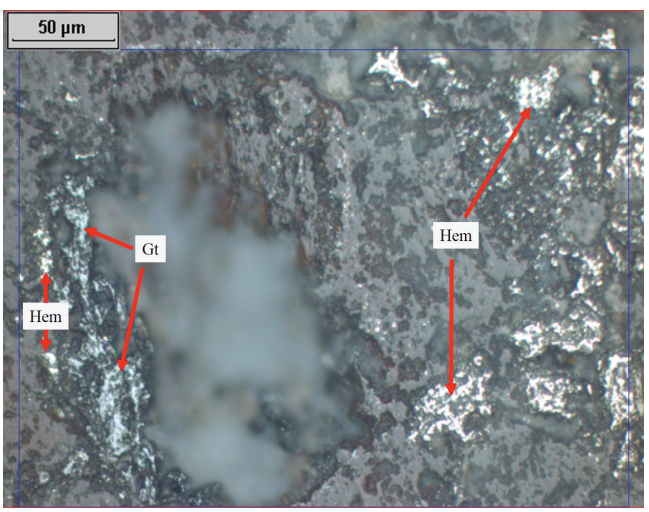

Figure 28- Hematite and geothite. On the left, hematites have altered into geothite.

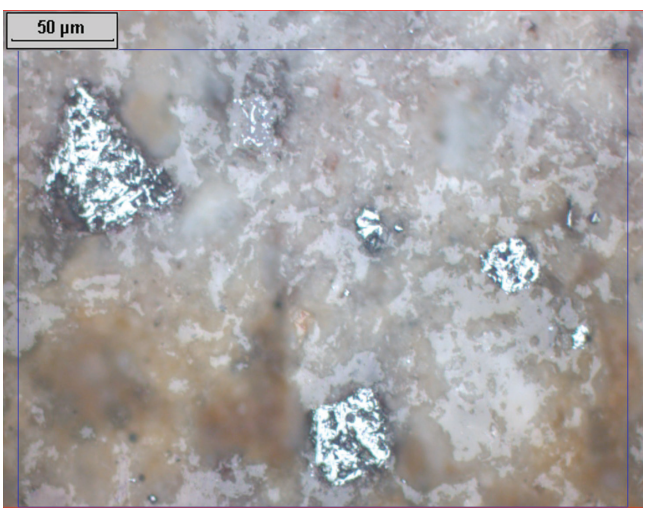

Figure 27- Hematite minerals in variable shapes (triangle, rectangle and amorphous) and sizes dispersed in the rock.

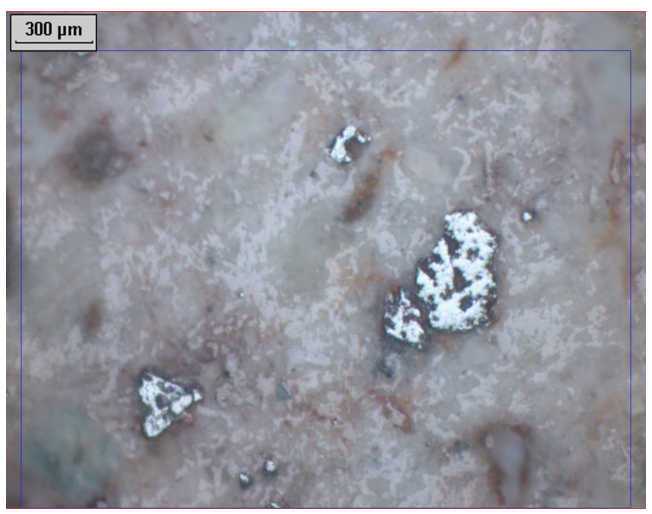

Figure 29- Hematite fully altered into geothite. 


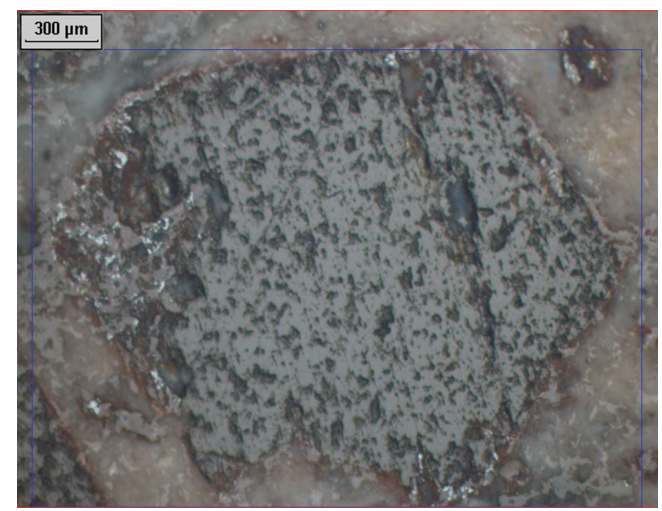

Figure 30- Hemtatite (white) and geothite (gray) formations observed on the circumference of an opacified amphibole grain.

\section{Discussion and Results}

Dutluca volcanics in sulfidic minerals consist of pyrite, enargite and chalcosine and in oxide minerals; magnetite, hematite and goethite. Magnetite is associated with the primary process, and the others are associated with secondary processes.

The most abundant opaque mineral in samples is pyrite; then goethite, hematite, magnetite and enargite minerals are observed in decreasing amount. Sulfur bearing solutions form abundant pyrite minerals reacting with iron which is present in the composition of the rock. The latter forming ore metals can substitute ferrous minerals and form new sulfide minerals (Krauskopf, 1987). Metals and sulfur may remain until low temperatures within excessively saturated solutions and continue to interact with the rock. Variable forms of pyritizations in studied volcanics approve this fact. Pyrite 1 and Pyrite 2 show at least in two stages that solutions with $\mathrm{H}_{2} \mathrm{~S}$ caused pyritization. Pyrite 3 has formed as a result of hydrothermal alteration of mafic minerals such as amphibole and biotite. As a result of reaction of some portion of iron which is dissolved from mafic minerals with solution enriched in sulfide pyrites in the form of fracture infilling have formed. These alterations might have formed in Pyrite 1 or Pyrite 2 or at an earlier stage. This relationship was not detected in microscope.

The type of formation of enargite in volcanics shows a parallelism with pyrite. Enargite is an important mineral of paragenesis, because enargite mineral indicates the high sulfidation. Mineralizations, which are defined as sulfidic or acidic sulfate type and show typical alteration as alunite \pm kaolinite \pm prophyllite, always contain enargite and differentiate from

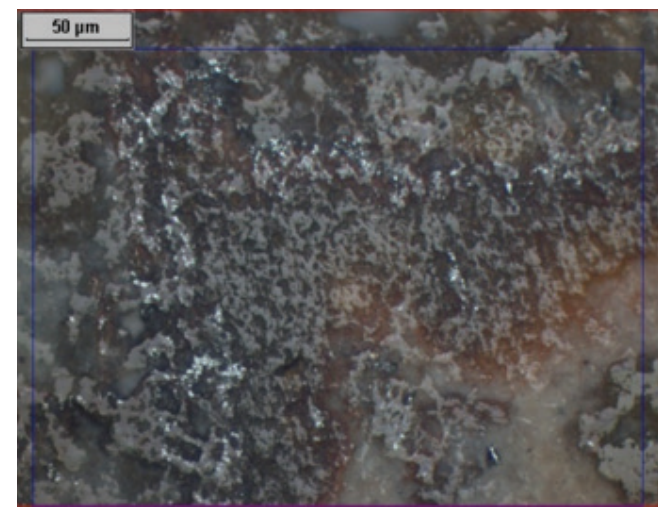

Figure 31- Highly opacified amphibole; hematite (white), geothite (gray).

adularia-sericite type mineralization (low sulfur) due to this characteristic (Silberman, 1982; Giles and Nelson, 1983).

The presence of few anisotropic chalcosine in samples indicates the formation of secondary sulfide minerals. The occurrence of magnetites is usual. Ramdohr (1969) states that magnetite mineral formed in many basalt, andesite and diabases. In studied samples, subhedral magnetites in fewer amounts than pyrite are seen. Martitizations in variable degrees have formed in many of these magnetites. There was not encountered any magnetite mineral which had been formed by the alteration of minerals such as biotite and hornblende. Hematite is the most abundant mineral in samples after pyrite. Hematite minerals are the secondary products associated with the alteration of opaque and ferrous silicate minerals.

Hematite is the stable mineral of iron in intermediate and oxidic environments. However; in reducing environments pyrite, siderite and magnetite become stable due to the concentration of sulfur and carbonate in solution. The transformation of minerals to each other by oxidizing occurs by means of basic solutions (Krauskopf, 1987). The martitization of magnetites in various degrees shows oxidic conditions and the non-presence of magnetite by hydrothermal alteration from silicates also supports this phenomena. The association of hematite-sulfur is not observed when the solution contains low sulfur. The association of hematite and enargite in studied samples indicates high sulfur concentration (Krauskopf, 1987).

Consequently; the opaque mineral paragenesis (occurrence of enargite in paragenesis), structures and textures reflecting the alteration of opaque and silicate 
minerals, which show opacification, indicate that studied volcanics have been altered by highly sulfidic hydrothermal solutions. Hydrothermal alteration process has developed in at least two phases.

Primary magnetite bearing volcanics have firstly caused a widespread pyritization under reducing conditions rich in $\mathrm{H}_{2} \mathrm{~S}$, and the formation of enargite which is known as pathfinder mineral in such processes. Later on; the oxygen in the environment has increased and intensive martitizations in oxidic conditions have developed.

\section{Acknowledgement}

This study has been carried out at the Ankara University, within scope of Scientific Investigation Projects (BAP) numbered as 13B4343012. We would like to thank to executives of BAP and to MTA (General Directorate of Mineral Research and Exploration) who helped during the collection of drill samples.

\section{References}

Akyürek, B., Soysal, Y. 1978. Kırkağaç-Soma (Manisa), Savaştepe-Korucu-Ayvalık (Balıkesir). Bergama (İzmir) civarının jeolojisi. Maden Tetkik ve Arama Genel Müdürlüğü Raporu, no.6432, Ankara (unpublished).

Bingöl, E., Akyürek, B., Korkmazer, B. 1973. Biga Yarımadasının jeolojisi ve Karakaya formasyonunun bazı özellikleri. Cumhuriyetin 50. yılı Yerbilimleri Kongresi Tebliğleri Kitabı, pp.7076, Ankara.

Çolakoğlu, A.R. 2000. Küçükdere (Havran-Balıkesir) epitermal altın damarlarının özellikleri. Türkiye Jeoloji Bülteni, c. 43, sayı 2, 99-110p.

Çolakoğlu, A.R., Sezerer Kuru, G. 2001. Küçükdere (Havran-Balıkesir) epitermal altın damarlarında sıvı kapanım çalışmaları. Yerbilimleri Dergisi, 24, pp.1-11.

Ercan, T. 1982. Batı Anadolu'nun Genç Tektoniği ve Volkanizması. Batı Anadolu'nun Genç Tektoniği ve Volkanizması Paneli, TJK Yayını, pp.5-14.

Ercan, T., Günay, E., Savasçın, M. Y. 1983. Simav ve çevresindeki Senozoyik yaşlı volkanizmanın bölgesel yorumlanmas1. Maden Tetkik ve Arama Genel Müdürlüğ̈̈ Dergisi 97\98, pp.86-101.

Ercan, T., Günay, E., Türkecan, A. 1984. Edremit-Korucu yöresinin (Balıkesir) Tersiyer Stratigrafisi magmatik kayaçların petrolojisi ve kökensel yorumu. Türkiye Jeoloji Kurumu Bülteni, C. 27, pp.21-30.
Ercan, T., Ergül, E., Akçören, F., Çetin, A., Granit, S., Asutay, J. 1990. Balıkesir-Bandırma arasının Tersiyer volkanizmasının petrolojisi ve bölgesel yayılımı. Maden Tetkik ve Arama Genel Müdürlüğü Dergisi 110, pp.113-130.

Giles, D. L., Nelson,C. E. 1983. Principal features of epithermal lode gold deposits of the circum-pacific rim: circum pacific. Energy Mineral Resource Conferance, 3rd, Honolulu, Hawaii, August 22-28, Trans., pp.273-278.

Hedenguist, J.W. 1985. Hydrothermal eruptions in the Waiotapu geothermal system, New Zealand: origin, breccia deposits and effects on precious metal mineralization. Economic Geolology, 80, pp.16401666.

Krauskopf, K. B. 1987. Introduction to Geochemistry. Mc Graw-Hill Book Company, 667p.

Krushensky, R.D. 1976. Neogene calcalkaline extrusive and intrusive rocks of the Karalar-Yeşiller area, northwest Anatolia. Bull. Volcan., 40, pp.336-360.

Ramdohr, P. 1969. The Ore Minerals and Their Intergrowths. Pergamon Press, 1174p.

Silberman, M.L. 1982. Hot-spring type, large tonnage, low grade gold deposit. U.S. Geol. Survey Open File Rept. 82-795, pp.131-143.

Simmons, S.F., White, N.C., John, D.A. 2005. Geological characteristics of epithermal precious and base metal deposits. Economic Geology, 100th Anniversary Volume, pp.485-522.

Şengör, A.M.C., Y1lmaz, Y. 1981. Tethyan evolution of Turkey: A plate tectonic approach. Tectonophysics, v. 75, pp.181-241.

Yiğit, Ö. 2012. A prospective sector in the Tethyan Metallogenic Belt: Geology and geochronology of mineral deposits in the Biga Peninsula, NW Turkey. Ore Geology Reviews, pp.118-148.

Yüzer, E., Tunay, G. 2012. Biga Yarımadasının Genel ve Ekonomik Jeolojisi. Maden Tetkik ve Arama Genel Müdürlüğü Özel yayın serisi 28., 326p., Ankara 
